JURNAL KACAPURI

JURNAL KEILMUAN TEKNIK SIPIL

Volume 3 Nomor 1 Edisi Juni 2020

\title{
EVALUASI KINERJA STRUKTUR MENARA RANGKA BAJA (DERRICK) BERDASARKAN PERIODE AISC
}

\author{
Miftahul Iman ${ }^{(1)}$ Azis Susanto ${ }^{(2)}$ \\ (1), (2) Dosen Program Studi Teknik Sipil, Universitas Borneo Tarakan \\ E-mail: anmfal@yahoo.com/HP.+6281215214107
}

\begin{abstract}
ABSTRAK
Tarakan adalah kota penghasil minyak yang telah dikenal sejak 1896. Derrick didefinisikan sebagai fasilitas pengeboran minyak bumi. Prototipe derrick dimodelkan dengan elemen rangka 3D dalam SAP2000. Tiga standar telah digunakan seperti AISCASD 1983; AISC-LRFD 1993; dan AISC 2010. Kombinasi beban angin ( $W$ ) dan gempa (E) telah dibandingkan. Analisis tekuk tunggal dan keseluruhan telah dipertimbangkan. Hasil penelitian menunjukkan bahwa struktur derick memenuhi persyaratan stabilitas dan kekuatan. Pengaruh kombinasi beban angin $(W)$ pada struktur derek lebih signifikan $(9,45 \%)$ daripada beban gempa (E). Beban tekan aksial terbesar maksimum 9,37 kN pada elemen kaki (legs). Kegagalan tekuk tidak terjadi pada struktur derrick. Beban kritis $\left(P_{c r}\right)$ tercatat 700,45 kN (Euler), 693,41 kN (tunggal), dan 219,67 kN (struktur).
\end{abstract}

Kata Kunci: tekuk, on shore, kapasitas, angin, rig

\section{ABSTRACT}

Tarakan is an oil-producing city that has been known since 1896. Derrick was defined as a petroleum drilling facility. The derrick prototype was modeled in $3 D$ frame elements by SAP2000. Three standards have been used such in AISC-ASD 1983; AISC-LRFD 1993; and AISC 2010. The load combination by wind (W) and quake (E) load had been compared. Single and overall buckling analysis had been conducted. The results showed that the derrick structure satisfied the stability and strength requirements. The effect of the wind load combination on the derrick structure was significant $(9,45 \%)$ than quake load (E). The largest axial compressive load was recorded in 9,37 $\mathrm{kN}$ at the legs element. Buckling failure did not occur in the derrick structure. The critical load $\left(P_{c r}\right)$ was recorded in $700.45 \mathrm{kN}$ (Euler), $693.41 \mathrm{kN}$ (single element), and $219.67 \mathrm{kN}$ (overall structure).

Keyword: buckling, on shore, capacity, wind, derrick 


\section{PENDAHULUAN}

Tarakan adalah salah satu kota penghasil minyak yang telah dikenal sejak 1896. Kegiatan eksplorasi minyak pertama kali di Tarakan diprakarsai oleh Bataavishe Petroleum Maatchapij (BPN). Begitu banyak infrastruktur pengeboran minyak (derrick) telah dibangun dan sebagian besar masih dapat ditemukan sekarang. Seiring bertambahnya waktu, beberapa dari struktur derrick ini tidak lagi digunakan. Penempatan struktur derrick sangat dekat dengan lintasan transportasi publik dan jaringan transmisi listrik. Situasi ini berpotensi menyebabkan bencana apabila struktur derrick tersebut mengalami kegagalan (derrick structure failure). Beban lingkungan seperti beban angin dan beban gempa dapat dipertimbangkan dalam situasi tersebut.

Dacovic dan Hegedic (2014) telah melakukan penelitian tentang pendekatan manajemen risiko dalam kegiatan konstruksi minyak dan gas di daratan. Hasil penelitian menunjukkan bahwa pendekatan kualitas terperinci dari proses manajemen risiko dapat dikaitkan dengan tingkat kesulitan risiko dalam kuantitas pengetahuan dan pengalaman dengan pendekatan risiko yang sangat terbatas dalam melakukan tindakan mitigasi terhadap infrastruktur-infrastruktur eksplorasi minyak bumi dan gas. Hasil penelitian juga menunjukkan perbedaan yang signifikan ketika dua pendekatan manajemen risiko yang berbeda ditetapkan dalam kegiatan tersebut. Miftahul dkk. (2019) telah mempelajari pengaruh dari korosi pitting yang membentuk lubang kecil pada sebuah logam sehingga dapat memicu kegagalan struktural dalam struktur platform. Hasil penelitian menunjukkan bahwa kapasitas tekuk struktur rangka secara keseluruhan (overall) dibandingkan dengan elemen struktur rangka yang mengalami kegagalan tekuk pada elemen struktur tersebut (single element) dan menerima beban tekan. Pemodelan menggunakan elemen rangka 3D dengan berbagai posisi lubang, beban tekuk yang terjadi pada sistem struktur rangka keseluruhan sedikit lebih tinggi daripada beban tekuk elemen. Solazzi dan Zrnić (2017) telah melakukan penelitian tentang desain kran yang sangat besar (boom utama panjangnya $80 \mathrm{~m}$ dan muatan $60 \mathrm{~T}$ ) dengan mempertimbangkan pengaruh dinamis yang disebabkan oleh proses transfer beban. Penelitian ini dikembangkan melalui model perhitungan analitis untuk desain awal kran dan menggunakan analisis metode beda hingga (FDM) untuk mengevaluasi perilaku dinamik kran tersebut. Hasil penelitian juga menunjukkan bahwa fenomena tekuk adalah titik pandang paling kritis untuk jenis kran ini.

Kombinasi beban telah disajikan dalam ASCE/ SEI 7-10. Beban gempa telah dievaluasi dengan analisis statik ekuivalen berdasarkan lokasi struktur derrick dan jenis tanah. Data beban angin diperoleh dari desain kecepatan angin yang diubah menjadi desain beban angin (Persamaan 1). Data kecepatan angin berasal dari Badan Meteorologi, Klimatologi dan Geo Fisika kota Tarakan, Indonesia.

$$
F=q_{z} G C_{f} A_{f}
$$

dengan:

$q_{z} \quad$ : Tekanan kecepatan angin yang dihitung pada ketinggian $z$

$G \quad:$ Faktor pengaruh hembusan angin

$C_{f} \quad$ : Koefisien gaya 
$A_{f} \quad$ : Luas area yang tegak lurus terhadap arah angina, kecuali dengan $C_{f} \quad$ yang telah ditentukanluas permukaan aktual, in, $\mathrm{ft}^{2},\left(\mathrm{~m}^{2}\right)$

Analisis tekuk telah dilakukan dalam penelitian ini. Ada dua analisis tekuk yang dilakukan dalam penelitian ini, yaitu: analisis tekuk untuk elemen tunggal (single) dan analisis tekuk sistem struktur rangka secara keseluruhan (overall). Formula Euler (Persamaan 2) telah digunakan untuk memverifikasi hasil beban kritis $\left(P_{c r}\right)$ dengan analisis tekuk linear (SAP2000).

$$
P_{c r}=\frac{\pi^{2} E I}{(K L)^{2}}
$$

Dengan $P_{c r}$ adalah beban kritis, $E$ adalah modulus elastisitas, $I$ adalah momen inersia, $K$ adalah koefisien kondisi batas, dan $L$ adalah panjang efektif. Persamaan 2 hanya cukup memenuhi persyaratan analisis tekuk kasus 1D. Sehubungan dengan hal tersebut, kondisi batas diasumsikan didukung oleh tumpuan sederhana sendi-rol (sistem sambungan baut). Itu sebabnya koefisien kondisi batas $(K)$ telah ditentukan $K=1$.

\section{METODE PENELITIAN}

Kombinasi pembebanan yang digunakan dalam penelitian ini adalah berturut-turut: $1,4 D$; $0,9 D+1,0 W$; dan $0,9 D+1,0 E$ dengan $D$ adalah beban mati, $W$ adalah beban angin, dan $E$ adalah beban gempa. Banyaknya aplikasi numerik berbasis metode elemen hingga (FEM) yang dapatkan menggambarkan simulasi kegagalan tekuk sebuah model struktur derrick 3D. Model struktur derrick 3D dapat dianalisis dengan menggunakan aplikasi numerik berbasis FEM yaitu SAP2000 versi 11.00. Beberapa sifat material baja seperti halnya modulus elastisitas $\left(E_{S}\right)$, rasio Poisson $(v)$, tegangan leleh $\left(F_{y}\right)$ dan tegangan ultimit $\left(F_{u}\right)$ sebagaimana yang telah ditentukan dalam spesifikasi material baja A36.

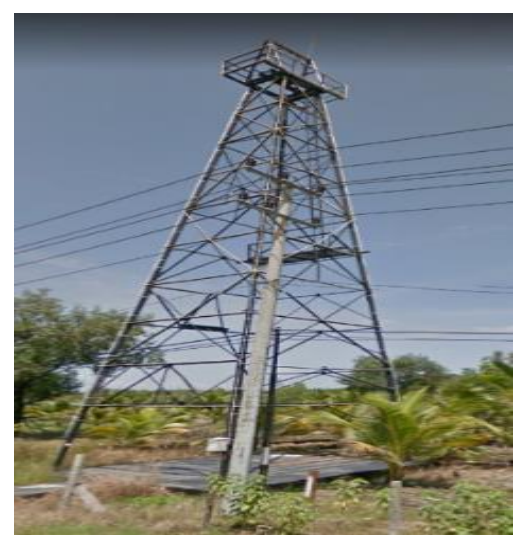

Gambar 1. Prototipe struktur derrick 
Model numerik yang digunakan dalam penelitian ini adalah model struktur rangka (truss) 3D yang tersedia di SAP2000. Prototipe yang dimodelkan dalam penelitian ini adalah prototipe struktur menara rangka baja (derrick) yang digunakan sebagai infrastruktur pengeboran minyak di daratan (on shore) oleh pemerintah kolonial Belanda di kota Tarakan. Model tersebut telah menginspirasi prototipe struktur menara rangka baja (derrick) yang terletak di Kampung 4, kota Tarakan, Indonesia (Gambar 1). Pemodelan yang dilakukan dengan SAP2000 adalah pemodelan numerik skala penuh.

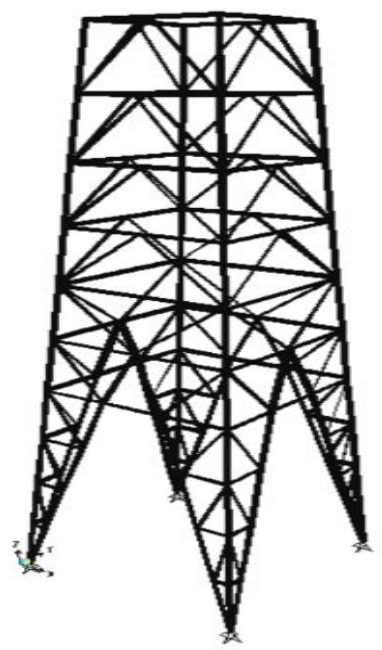

Gambar 2. Model 3D struktur derrick utuh

Pemodelan numerik dalam penelitian ini berkaitan dengan model struktur menara rangka baja (derrick) yang utuh (perfect). Model yang utuh tersebut didefinisikan sebagai struktur menara rangka baja (derrick) yang elemen strukturnya masih lengkap. Model dibangun berdasarkan rekonstruksi pada kondisi aktualnya (Gambar2). Analisis struktur yang dilakukan pada model yaitu analisis statis, analisis statis ekuivalen untuk beban angin dan beban gempa, serta analisis tekuk.

Gaya-gaya dalam, deformasi, dan perpindahan telah dievaluasi untuk dibandingkan satu sama lain. Analisis tekuk dibedakan dalam dua cara yaitu analisis tekuk linier dan nonlinier. Data material menggunakan tipe material baja A36 ( $F_{y}=36 \mathrm{Ksi}$ dan $F_{u}=58$ Ksi). Model yang dibangun diasumsikan memiliki kinerja dan kualitas yang sama ketika prototipe struktur menara rangka baja (derrick) pertama kali dibangun.

Analisis struktur dilakukan dengan menggunakan SAP2000 versi 11,00 dengan ijin sewa (lisence) oleh Laboratorium Komputer Departemen Teknik Sipil dan Lingkungan, Universitas Gadjah Mada. Analisis desain yang telah dilakukan menggunakan peraturan (standard) AISC-ASD 1983, AISC-LRFD 1993, dan AISC 2010. 


\section{HASIL DAN PEMBAHASAN}

Analisis struktur telah dilakukan untuk mengevaluasi gaya-gaya aksial elemen struktur menara rangka baja (derrick). Gaya aksial terdiri dari 2 jenis yaitu: gaya aksial tarik dan gaya aksial desak yang bekerja pada elemen tersebut untuk kemudian dibandingkan (Tabel 1). Gaya aksial terbesar (aksial desak) telah ditunjukkan oleh diagram gaya normal (NFD) pada Gambar 3. Gaya normal yang dihasilkan adalah berdasarkan kombinasi pembebanan yang telah ditentukan oleh masing-masing peraturan (codes). Beban mati $(D)$ akibat berat sendiri (self weight) telah dihitung secara otomatis oleh SAP2000 versi 11.00.

Tabel 1. Gaya-gaya aksial

\begin{tabular}{cccccccccc}
\hline The & \multicolumn{3}{c}{ AISC-ASD 1989 } & \multicolumn{4}{c}{ AISC-LRFD 1993 } & \multicolumn{3}{c}{ AISC-2010 } \\
$\begin{array}{c}\text { axial } \\
\text { force }\end{array}$ & $\mathrm{D}$ & $\mathrm{D}+\mathrm{E}$ & $\mathrm{D}+\mathrm{W}$ & $1,4 \mathrm{D}$ & $0,9 \mathrm{D}+\mathrm{E}$ & $0,9 \mathrm{D}+1,3 \mathrm{~W}$ & $1,4 \mathrm{D}$ & $0,9 \mathrm{D}+\mathrm{E}$ & $0,9 \mathrm{D}+\mathrm{W}$ \\
$\mathrm{kN})$ & & & & & & & & & \\
\hline $\mathrm{T}$ & 0,67 & 2,81 & 1,33 & 0,93 & 2,89 & 1,46 & 0,93 & 2,89 & 1,26 \\
$\mathrm{C}$ & 4,15 & 6,72 & 8,09 & 5,80 & 6,47 & 9,37 & 5,80 & 6,47 & 7,80 \\
\hline
\end{tabular}

Tabel 1 menunjukkan bahwa kombinasi beban angin berpengaruh sangat signifikan terhadap pembesaran gaya-gaya aksial yang bekerja pada struktur menara rangka baja (derrick). Beban angin maksimum telah ditunjukkan dalam kombinasi beban $0,9 D+1,3 \mathrm{~W}$ $(9,12 \mathrm{kN})$ berdasarkan peraturan AISC-LRFD 1993. Gaya batang aksial maksimum telah didefinisikan sebagai gaya batang aksial desak untuk setiap kasus kombinasi pembebanan.

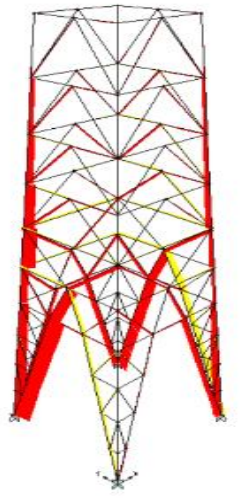

(i)

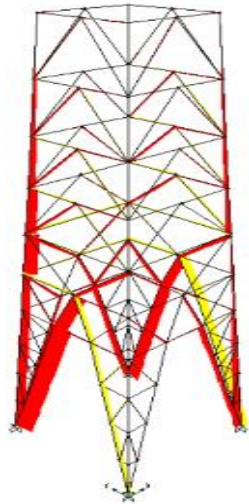

(ii)

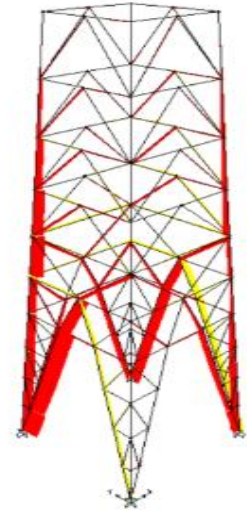

(iii)

Gambar 3. Normal Force Diagram (NFD)

Gambar 3 telah menunjukkan diagram gaya normal (NFD) untuk tiga kasus kombinasi pembebanan. Ketiga kombinasi pembebanan tersebut yang melibatkan beban angin $(W)$ adalah: $D+W$ (i); $0,9 D+1,3 W$ (ii); dan $0,9 D+W$ (iii), di mana $D$ adalah beban mati dan $W$ adalah beban angina. Gambar 3 juga telah menunjukkan bahwa beban aksial desak 
maksimum terjadi pada elemen 233 (elemen kaki dari struktur menara rangka baja, derrick).

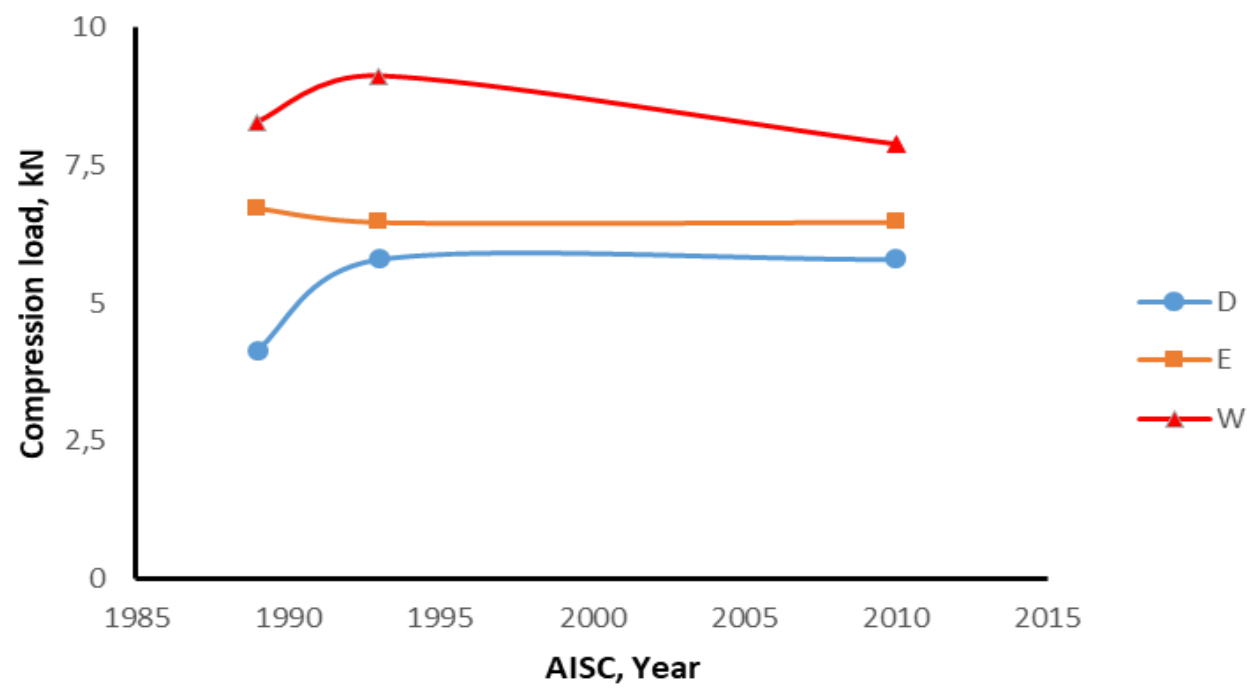

Gambar 4. Normal compressive axial force curve

Gambar 4 menunjukkan perbandingan kurva beban aksial desak dari struktur menara rangka baja (derrick) dengan setiap kombinasi pembebanan berdasarkan peraturan (standard) America Intitute Steel Construction (AISC). AISC-1993 memiliki faktor beban angin terbesar dibandingkan dengan kombinasi beban angin yang menggunakan peraturan (codes) lainnya . Hal tersebut mengakibatkan gaya-gaya aksial berdasarkan AISC-1993 memiliki gaya-gaya aksial desak relatif terbesar. Kombinasi pembebanan yang digunakan adalah $0,9 D+1,3 W$, dengan $D$ dan $W$ berturut-turut adalah beban mati dan beban angin. Persentase kombinasi beban angin pada beban lain yaitu 37,58\% dan 9.45\% (1.4D) and $21,96 \%$ untuk kombinasi beban mati dan beban gempa.

Gambar 4 juga telah menunjukkan bahwa kombinasi beban gempa dengan analisis statik ekuivalen tidak berpengaruh signifikan terhadap kinerja derek. Persentase kombinasi beban gempa dan berat sendiri struktur menara rangka baja (derrick) 19,65\% untuk setiap AISC. Meskipun demikian kerentanan dan resiko kegagalan struktur akibat beban gempa harus dipertimbangkan dalam setiap desain struktur rangka baja, terutama di zona merah bahaya gempa. 
JURNAL KACAPURI

JURNAL KEILMUAN TEKNIK SIPIL

Volume 3 Nomor 1 Edisi Juni 2020

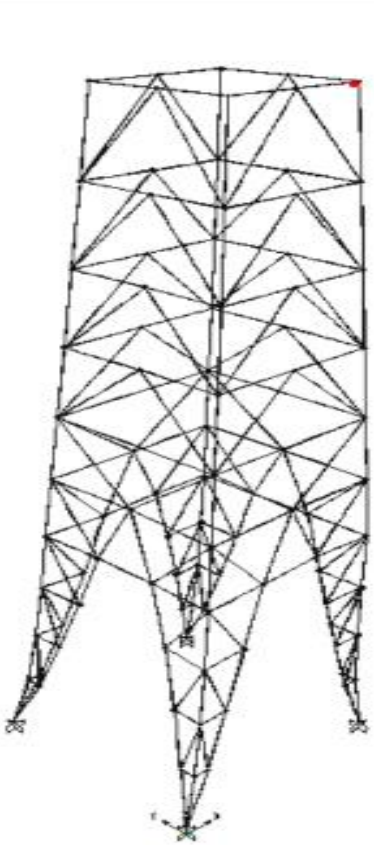

(i)
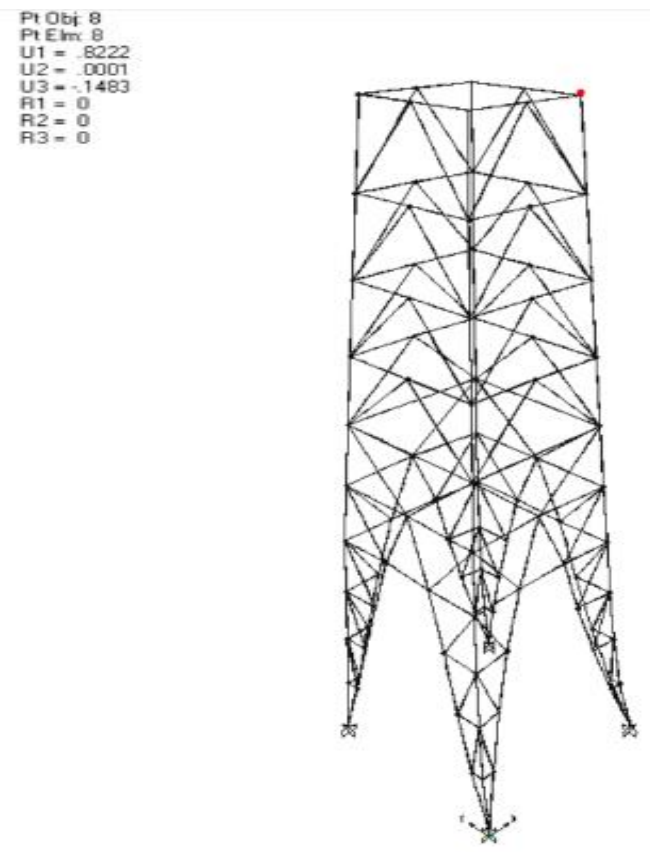

(ii)

Gambar 5. Aksi beban lateral pada struktur derrick

Gambar 5 telah menunjukkan bagaimana beban lateral bekerja pada struktur menara rangka baja (derrick). Gambar 5(i) menunjukkan deformasi struktur derrick yang disebabkan oleh beban gempa (seismic load). Beban gempa bekerja yang bekerja pada arah $x$ dengan kombinasi pembebanan $0,9 D+E x$. Perpindahan (displacement) di salah satu join bagian atas struktur derrick (nodal 8 ) tercatat $0,822 \mathrm{~mm}$. Nilai ini masih diizinkan dalam persyaratan keselamatan sebuah struktur akibat beban gempa. Displasemen akibat beban gempa pada arah $y$ juga telah dievaluasi $\left(U_{2}=0,822 \mathrm{~mm}\right)$.

Gambar 5 (ii) telah menunjukkan aksi beban lateral pada struktur menara rangka baja (derrick) yang disebabkan oleh kombinasi beban angin. Desain kecepatan angin sebesar 34,18 mph (30 knot) yang bekerja dalam arah $x$ dan $y$ dengan sudut beban 79.890. Kombinasi beban yang bekerja dalam struktur menara rangka baja (derrick) menggunakan kombinasi pembebanan $0,9 D+1,3 W_{x}$ berdasarkan AISC-LRFD 1993. Displasemen yang terjadi pada salah satu join di atas struktur derrick (nodal 8) telah dievaluasi sebesar 1,18 $\mathrm{mm}$ ke arah $y$. Nilai tersebut telah diizinkan displasemen ijin persyaratan struktur desain baja.

Lokasi struktur menara rangka baja (derrick) harus dipertimbangkan untuk mengevaluasi kinerja struktur derrick tersebut. Khususnya apabila struktur menara rangka baja (derrick) terletak sangat dekat dengan beberapa fasilitas berbahaya seperti tiang transmisi listrik yang sering ditemukan di sepanjang lokasi derrick tersebut. Selain itu, kerentanan bahaya juga dapat terjadi apabila struktur derrick dengan lintasan jalan umum. Beban lateral 
seperti halnya beban seismik dan angin harus dipertimbangkan. Perpindahan (displacement) beberapa nodal wajib dievaluasi akibat beban lateral.

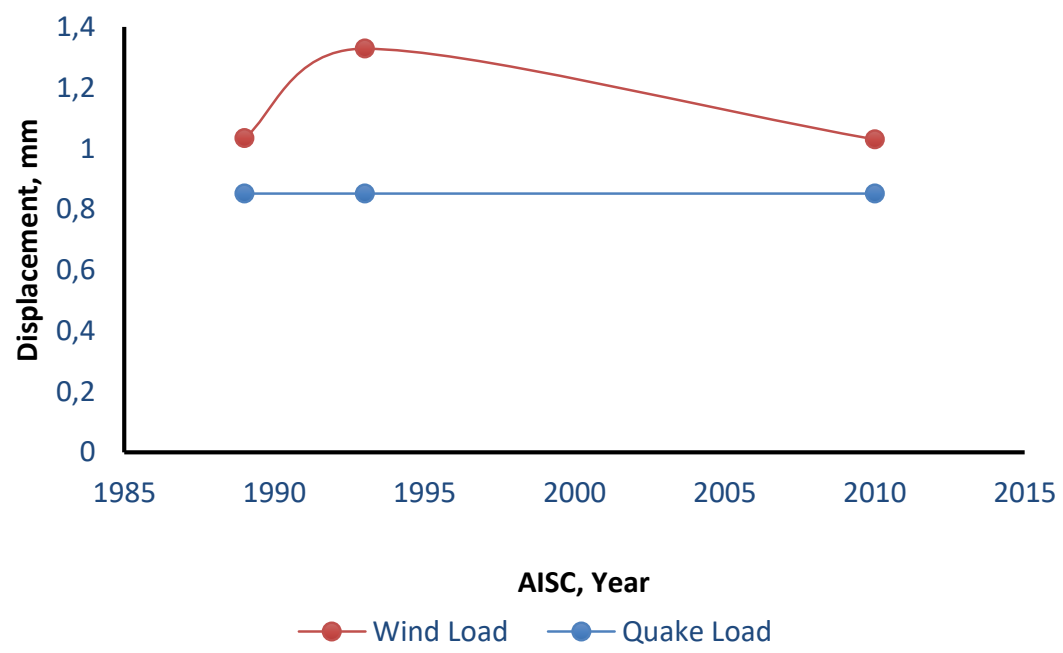

Gambar 6. Perbandingan kurva displasemen

Gambar 6 telah menunjukkan perbandingan kurva perpindahan (displacement) yang disebabkan oleh beban lateral (beban gempa dan beban angin). Perbandingan kurva berdasarkan pada AISC yang telah ditentukan. Perpindahan maksimum telah dievaluasi dalam arah lateral pada struktur derrick. Kombinasi beban masing-masing diketahui: $D+E ; D+W ; 0,9 D+E: 0,9 D+1,3 W ;$ dan $0,9 D+W$, di mana $D$ adalah beban mati, $E$ adalah beban gempa, dan $W$ adalah beban angin.

Gambar 6 juga telah menunjukkan bahwa perpindahan yang disebabkan oleh 'beban gempa relatif konstan. Situasi ini disebabkan oleh tidak adanya perubahan faktor beban yang signifikan pada setiap perubahan tahun peraturan (code) AISC (1993-2010). Faktor beban gempa $(E)$ dalam hal ini adalah 0,9 untuk faktor kombinasi beban $D$ dan $E$ dalam desain faktor resistensi beban (LRFD) AISC. Kurva kombinasi beban gempa terletak di bawah kurva kombinasi beban angin. Situasi ini menjelaskan bahwa analisis statik ekuivalen untuk kombinasi beban gempa relatif lebih rendah dari kombinasi beban angin (Gambar 3(ii) dan Gambar (iii)).

Nilai kombinasi beban angin dalam AISC-LRFD 1993 adalah yang tertinggi dari setiap nilai kombinasi beban lateral. Situasi ini disebabkan oleh faktor beban angin paling tinggi $(1,3 \mathrm{~W})$ dari setiap kombinasi pembebanan yang telah diberikan untuk sistem struktur menara rangka baja (derrick). Persentase perpindahan (displacement) yang dicapai oleh kombinasi beban angin adalah 35,92\% terhadap kombinasi beban gempa pada tahun yang sama (1993). Beban angin dengan kecepatan 34 knot memberikan risiko kegagalan lebih besar daripada beban gempa dengan analisis statis ekuivalen terhadap struktur derrick. 
Stabilitas struktur derrick juga telah dievaluasi. Analisis tekuk dilakukan dalam dua cara: analisis tekuk tunggal (elemen) 2D dan analisis tekuk struktur 3D keseluruhan (overall) dengan menggunakan elemen rangka (truss) 3D. kegagalan tekuk didefinisikan sebagai beban kritis $\left(P_{c r}\right)$ yang dicapai ketika sebuah elemen mengalami tekuk. Elemen yang ditinjau adalah elemen yang memiliki beban aksial desak terbesar $(9,37 \mathrm{kN})$ yang terjadi pada elemen 223 (legs).

Gambar 7 menunjukkan pola tekuk satu elemen (elemen 223) yang terjadi pada mode pertama. Pola tekuk yang telah ditunjukkan sesuai dengan pola tekuk teoritik (single curvature). Elemen rangka 2D diberikan tumpuan sendi rol (simply supported) sebagaimana yang ditunjukkan oleh Gambar 7.

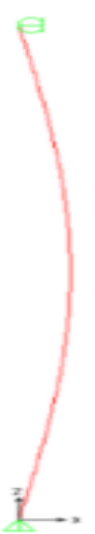

Gambar 7. Pola tekuk satu elemen pada mode pertama

Elemen tunggal telah mencapai beban kritis $\left(P_{c r}\right)$ pada $700,45 \mathrm{kN}(70 \mathrm{~T})$ dengan rumus Euler. Analisis tekuk numerik dengan nilai eigen (SAP2000) memberikan angka beban kritis 693,41 kN (69,34 T). Persentase perbedaan antara dua analisis tekuk (nilai Euler dan eigen) $1,01 \%$ terhadap rumus Euler. Nilai $P_{c r}$ berdasarkan hasil analisis tekuk liner (nilai eigen) lebih besar dari pada nilai $P_{c r}$ hasil analisis Euler dengan gaya aksial desak terbesar terdapat pada elemen 223. Kondisi ini telah menjelaskan bahwa elemen 223 tidak mengalami kegagalan tekuk.

Pola tekuk lainnya dalam mode yang berbeda tidak menjadi fokus penelitian kami. Mode pertama dari pola tekuk lebih menggambarkan kondisi aktual struktur elemen derrick ketika beban tekuk terjadi. Kondisi tersebut menujukkan bahwa kegagalan tekuk tidak terjadi karena struktur tersebut gagal disebabkan oleh materialnya (bukan kegagalan geometrik). Gaya aksial desak terbesar $\left(P_{u}\right)$ tercatat $9,37 \mathrm{kN}$ (limit state) dan beban kritis $\left(P_{c r}\right)$ tercatat $700,45 \mathrm{kN}$ yang menjelaskan bahwa kegagalan struktur elemen desak (233) disebabkan oleh kegagalan material. Rasio kelangsingan $(K L / r)$ elemen 233 menunjukkan bahwa elemen tersebut dapat diklasifikasikan ke dalam kriteria kolom pendek $(K L / r$ $<100)$. 


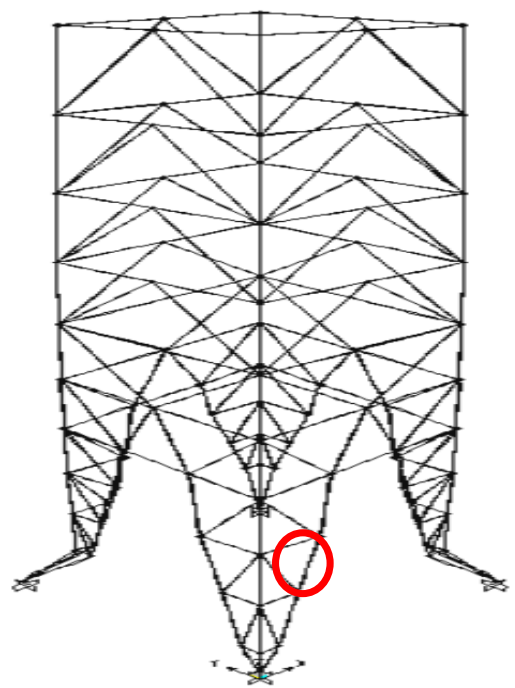

Gambar 8. Pola tekuk pada mode pertama (overall structure buckling)

Gambar 8 menunjukkan pola tekuk struktur derrick secara global yang terjadi pada mode pertama. Beban kritis $\left(P_{c r}\right)$ dalam struktur derrick keseluruhan telah dievaluasi $(21,90 \mathrm{~T})$. Berdasarkan hasil penelitian bahwa beban kritis $\left(P_{c r}\right)$ dari hasil analisis tekuk struktur keseluruhan (overall) lebih rendah dari hasil analisis tekuk elemen tunggal. Persentase perbedaannya adalah $68,73 \%$ terhadap beban kritis tekuk elemen tunggal.

Gambar 8 juga menunjukkan bahwa deformasi tekuk terjadi pada elemen kaki (leg) struktur derrick (elemen 223). Elemen 223 memiliki beban aksial desak maksimum. Meskipun demikian dalam kenyataan kegagalan tekuk tidak akan terjadi pada elemen kaki struktur derrick. Hal tersebut karena tegangan kritis $\left(F_{c r}\right)$ lebih tinggi dari tegangan leleh $\left(F_{y}\right)$ yang dimiliki elemen tersebut. Dengan kata lain elemen struktur derrick dapat mengalami kegagalan struktur apabila telah mencapai tegangan leleh material $\left(F_{y}=36\right.$ Ksi) yang disebut sebagai kegagalan material (material failure).

Table 1. Beban kritis $\left(P_{c r}\right)$

\begin{tabular}{ccc}
\hline Model & \multicolumn{2}{c}{ Beban kritis $\left(P_{c r}\right)(\mathbf{N})$} \\
& Euler & Eigen value \\
\hline Single element & 700452,4899 & 693410,09 \\
Overall structure & - & 219665 \\
\hline
\end{tabular}

Tabel 1 menunjukkan beban kritis $\left(P_{c r}\right)$ elemen tunggal dan keseluruhan elemen (overall) struktur derrick. Formula Euler yang tercantum dalam Persamaan 2 hanya untuk kasus dimensi saja sehingga hanya dapat memenuhi persyaratan tekuk elemen tunggal. Selanjutnya, untuk analisis tekuk dalam sudut padang struktur secara keseluruhan maka metode elemen hingga 3D adalah salah satu solusi yang terbaik untuk persoalan tekuk 3D. Analisis elemen hingga (FEA) 3D memanfaatkan aplikasi numerik berbasis elemen 
hingga (FE) SAP2000 untuk memperoleh solusi tekuk. Solusi tekuk dapat diperoleh dengan cara yaitu dengan analisis tekuk linear (solusi nilai eigen).

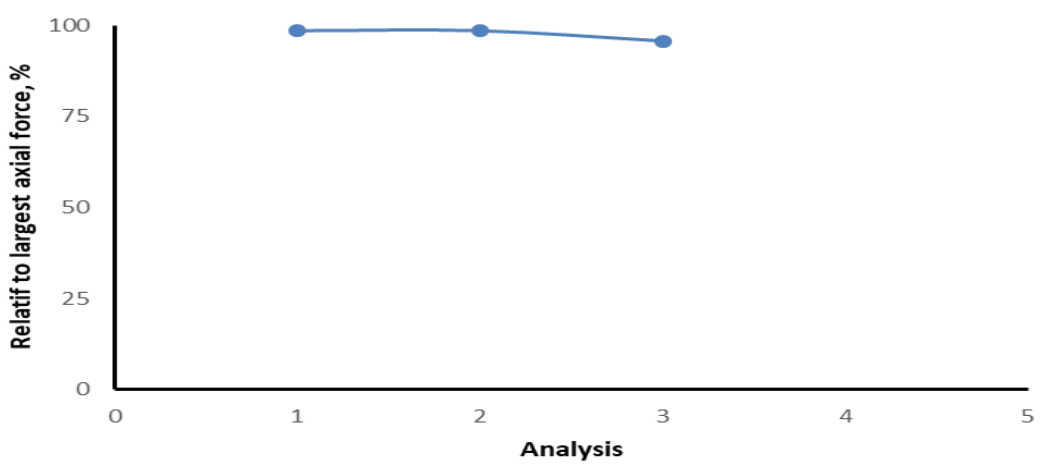

Gambar 9. $P_{c r} / P_{u}$ Curve

Gambar 9 menunjukkan kurva tren persentase relatif dari kritis $\left(P_{c r}\right)$ terhadap beban ultimit $\left(P_{u}\right)$ yang disebut sebagai rasio $P_{c r} / P_{u}$. Beban ultimit $\left(P_{u}\right)$ telah ditentukan berdasarkan gaya desak aksial terbesar $(9,71 \mathrm{kN})$. Analisis telah dilakukan sesuai dengan formula Euler (1), analisis nilai eigen: tekuk elemen tunggal (2), dan tekuk struktur derrick keseluruhan (overall) (3). Berdasarkan Gambar 9, tekuk struktur keseluruhan (overall) memiliki beban kritis $\left(P_{c r}\right)$ terendah.

Tidak ada perbedaan yang signifikan antara hasil analisis tekuk berdasarkan rumus Euler (Persamaan 2) dan analisis tekuk linier berdasarkan nilai eigen $( \pm 1 \%)$ untuk elemen tunggal. Persentase perbedaan beban kritis $\left(P_{c r}\right)$ hasil analisis tekuk elemen tunggal terhadap gaya aksial terbesar diketahui $98,66 \%$. Persentase beban kritis $\left(P_{c r}\right)$ berdasarkan analisis tekuk struktur keseluruhan (overall) terhadap elemen desak aksial terbesar adalah 95,74\%. Angka-angka ini menunjukkan bahwa kegagalan tekuk tidak pernah terjadi dalam struktur sistem menara rangka baja (derrick). Ada dua alasan untuk kasus ini: Pertama adalah elemen konfigurasi sistem struktur derrick memenuhi persyaratan stabilitas. Alasan kedua untuk kasus ini adalah rasio kelangsingan $(K L / r)$ dari elemen yang ditinjau (233) adalah 63,49. Hal ini menjelaskan bahwa elemen 233 yang memiliki dengan gaya desak aksial terbesar tidak termasuk batang langsing (slenderness member) sebagai salah satu syarat kegagalan tekuk dapat terjadi.

\section{Kesimpulan}

\section{PENUTUP}

Berdasarkan hasil analisis numerik dari pemodelan sistem struktur menara rangka baja (derrick) dapat disimpulkan sebagai berikut: Secara umum, struktur menara rangka baja (derrick) memenuhi persyaratan stabilitas dan kekuatan. Kombinasi beban lingkungan 
seperti ini halnya beban gempa dan beban angin telah diikutkan dalam analisis struktur menara rangka baja (derrick). Pengaruh kombinasi beban angin $(W)$ pada struktur menara rangka baja (derrick) lebih signifikan $(9,45 \%)$ daripada pengaruh kombinasi beban gempa $(E)$. Kombinasi beban yang telah dilakukan adalah $0,9 D+1,0 W$ (AISC-LRFD 1993). Beban desak aksial maksimum tercatat $9,37 \mathrm{kN}$ pada elemen kaki dari struktur derrick (elemen 223). Kegagalan tekuk tidak terjadi pada struktur derrick. Terdapat dua alasan untuk kasus ini yaitu: nilai beban kritis yang dicapai lebih besar dari beban lelehnya (baja A36). Kedua, elemen yang memiliki gaya desak aksial terbesar tidak termasuk dalam kategori elemen langsing $(K L / r=63,49 \leq 100)$. Beban kritis tertinggi $\left(P_{c r}\right)$ tercatat di $700,45 \mathrm{kN}$ (Euler), 693,41 kN (elemen tunggal) dan 219,67 kN (tekuk struktur keseluruhan). Kedua nilai terakhir beban kritis $\left(P_{c r}\right)$ diperoleh berdasarkan analisis tekuk linier (eigen value).

\section{Ucapan Terima Kasih}

Penulis sangat berterima kasih kepada Dr.-Eng Fikris Haris, S.T., M.Eng yang telah mengizinkan dan mendukung atas penggunaan lisensi SAP2000 di Laboratorium Komputer Departemen Teknik Sipil dan Lingkungan, Universitas Gadjah Mada.

\section{DAFTAR PUSTAKA}

ASCE SEI 7-10, Minimum Design Loads for Buildings and Other Structures: American Society of Civil Engineering, 2010, pp. 320.

AISC ASD, Specification for Structural Steel Buildings Allowable Stress Design and Plastic Design: American Institute Steel Construction, 1989, pp. 40-44.

AISC LRFD, Load and Resistance Factor Design Specification for Structural Steel Buildings: American Institute Steel Construction, 1993, pp. 36-41.

AISC LRFD, Specification for Structural Steel Buildings ANSI/AISC 360-10: American Institute Steel Construction, 2010, pp. 36-41. Dakovic, M. and Hegedic, M. Risk Management Approaches in Oil and Gas Onshore Constructions Projects (Project Management), Faculty of Mechanical Engineering and Naval Architecture University of Zagreb Croatia. Product Development, Production Technologies, 2014

Luigi Solazzi. and Nenad Zrnić. Design of a High Capacity Derrick Crane Considering The Effects Induced by Load Application and Release. Original Scientific Paper, 409, 2017, pp. 15 - 24.

Miftahul I., Bambang S., Priyosulistyo HRc., Muslikh. Experimental and Numerical Investigations on Overall Buckling of Steel Pipe Truss with Circular Cutout on The Compression Element. MATEC Web of Conference, 258, 2019, pp. 1-7. 